Матеріали науково-практично конференці з участю міжнародних спеціалістів «Актуальні питання діагностики, лікування, раціонально фармакотерапі, диспансеризаці та реабілітаці в практиці сімейного лікаря»

\title{
ОЦІНКА АНТИБІОТИКОРЕЗИСТЕНТНОСТІ УРОПАТОГЕНІВ ПРИ ІНФЕКЦІЯХ СЕЧОВИХ ТА СТАТЕВИХ ШЛЯХІВ
}

\author{
ОІ. Д. Андреєва, Т. П. Осолодченко, І. С. Рябова, Н. П. Завада, \\ О. А. Батрак, Т. В. Лук'яненко \\ ДУ «Інститут мікробіології та імунології ім. І. І. Мечникова НАМН України»
}

Інфекці сечовивідних та статевих шляхів відносять до найпоширеніших видів патологі людини. Джерелом інфекцій сечових та статевих шляхів 6 нормальна мікрофлора, що колонізує періуретральну ділянку та дистальний відділ сечовипускального каналу. За останні роки спостерігається значне збільшення резистентності уропатогенів до антибактеріальних препаратів.

Метою дослідження стало дослідження ступеня антибіотикорезистентності клінічно значущих штамів мікроорганізмів, вилучених у хворих з інфекціями сечовивідних і статевих шляхів, які перебували на позалікарняному лікуванні.

Матеріали та методи. Досліджено 78 клінічних ізолятів мікроорганізмів, вилучених від хворих на запальні захворювання сечових та статевих шляхів, які перебували на амбулаторному лікуванні в поліклінічному відділенні Комунального закладу охорони здоров'я «Харківська міська клінічна лікарня № 13». Забір матеріалу проводили до початку антибактеріально терапі . Ідентифікацію мікроорганізмів здійснювали загальноприйнятими методами згідно з діючими нормативними документами. Дослідження чутливості мікроорганізмів до антибактеріальних препаратів проводили за диско-дифузійним методом з використанням стандартних комерційних дисків на середовищі Мюлера-Хінтона у відповідності з Наказом Міністерства охорони здоров'я Укра ни від 05.04.2007 р. № 167. Статистична обробка отриманих даних проведена із використанням Excel та STATISTICA 8,0.

Результати дослідження. Майже у половини $(48,8$ \%) хворих з запальними процесами у сечовивідних та статевих шляхах вилучалися мікроор- ганізми родини Enterobacteriaceae, переважно E. coli, у чверті $(25,6 \%)$ - збудники грибкових інфекцій, у $15,4 \%$ - Streptococcus spp. та у 5,4\% - E. faecalis. Серед досліджених штамів ентеробактерій 40,0\% були стійкі до цефалоспоринів II та 16,7 \% - до цефалоспоринів III покоління, 63,3 \% - до ампіциліну, 33,3 \% - до інгібіторозахищених пеніцилінів, $30,0 \%$ - до сульфаніламідів та 23,3 \% - до норфлоксацину. Переважна більшість ентеробактерій (понад 90,0 \%) були чутливими до цефалоспоринів IV покоління, нітрофуранто ну, фосфоміцину, карбапенемів та амікацину. Штами грибів C. albicans у 88,6 \% випадків були чутливі до ністатину, у 80,0 \% до клотримазолу, у 77,1 \% - до амфотерицину В та у 71,4 \% - до кетоконазолу. Менш чутливі ізоляти C. albicans були до флуконазолу та ітраконазолу (57,1 \% і 60,0 \% відповідно). Відсоток стійких до антимікотиків штамів C. albicans коливався від 8,6 до $17,1 \%$. Переважна більшість вилучених штамів бета-гемолітичних стрептококів була помірно стійка до фторхінолонів $(52,4 \%)$, хлорамфеніколу $(66,7 \%)$, макролідів $(85,7 \%)$ та резистентна до лінкозамідів $(90,5$ \%). У чверті досліджених штамів ентерококів спостерігалась резистентність до ампіциліну. У всіх досліджених штамів E. faecalis спостерігалась помірна стійкість до похідних нітрофурану та хінолону II та III поколінь. Усі виділені штами ентерококів були чутливі до фосфоміцину.

Висновки. Визначення чутливості уропатогенів до антибактеріальних препаратів сприяє удосконаленню тактики лікування запальних захворювань сечовивідних та статевих шляхів за рахунок можливості проведення цілеспрямовано антибактеріально терапі . 